\title{
A study of single nucleotide polymorphism in the ystB gene of Yersinia enterocolitica strains isolated from various wild animal species
}

\author{
Agata Bancerz-Kisiel', Anna Szczerba-Turek1', Aleksandra Platt-Samoraj', Maria Michalczyk2, \\ Wojciech Szweda'

\begin{abstract}
${ }^{1}$ Department of Epizootiology, Faculty of Veterinary Medicine, University of Warmia and Mazury, Olsztyn, Poland
2 Department of Parasitology and Invasiology, Faculty of Veterinary Medicine, University of Warmia and Mazury, Olsztyn, Poland
\end{abstract}

Bancerz-Kisiel A, Szczerba-Turek A, Platt-Samoraj A, Michalczyk M, Szweda W. A study of single nucleotide polymorphism in the ystB gene of Yersinia enterocolitica strains isolated from various wild animal species. Ann Agric Environ Med. 2017; 24(1): 56-61. doi: 10.5604/12321966.1230737

\begin{abstract}
Introduction and objective. $Y$. enterocolitica is the causative agent of yersiniosis. The objective of the article was a study of single nucleotide polymorphism in the $y s t B$ gene of $Y$. enterocolitica strains isolated from various wild animal species.

Materials and method. High-resolution melting (HRM) analysis was applied to identify single nucleotide polymorphism (SNP) of ystB gene fragments of 88 Y. enterocolitica biotype $1 A$ strains isolated from wild boar, roe deer, red deer and wild ducks.

Results. HRM analysis revealed 14 different melting profiles -4 of them were defined as regular genotypes (G1, G2, G3, G4), whereas 10 as variations. 24 of the examined Y. enterocolitica strains were classified as G1, 18 strains as a G2, 21 strains as a G3, and 15 strains as a G4. Nucleotide sequences classified as G1 revealed 100\% similarity with the Y. enterocolitica D88145.1 sequence (NCBI). Analysis of $\mathrm{G} 2$ revealed one point mutation - transition T111A. One mutation was also found in $\mathrm{G} 3$, but SNP was placed in a different gene region - transition G193A. Two SNPs - transitions G92C and T111A - were identified in G4. Direct sequencing of 10 variations revealed 5 new variants of the ystB nucleotide sequence: V1 - transition G129A (3 strains); V2 - transitions T111A and G193A (2 strains); V3 - transitions C118T and G193A (1 strain); V4 - transitions C141A and G193A (2 strains); and V5 characterized by 19 SNPs: G83A, T93A, A109G, G114T, C116T, A123G, T134C, T142G, T144C, A150C, G162A, T165G, T170G, T174A, T177G, G178A, A179G, A184G and G193A (2 strains). The predominant genotype in isolates from wild ducks was G1; in red deer G2; in wild boar G3; in roe deer G1 and G4.

Conclusions. The proposed HRM method could be used to analyze Y. enterocolitica biotype $1 \mathrm{~A}$ strains isolated from different sources, including humans.
\end{abstract}

\section{Key words}

HRM, SNP, wild animal species, Y. enterocolitica; ystB

\section{INTRODUCTION AND OBJECTIVES}

According to EFSA (European Food Safety Authority) reports, Yersinia enterocolitica is one of the most important foodborne pathogens. The epidemiology of Y. enterocolitica infections is complex and not fully elucidated, because the pathogen widely colonizes terrestrial and aquatic habitats, and various animals species $[1,2,3,4,5,6]$.

Not all $Y$. enterocolitica strains are pathogenic for humans and animals. Strains belonging to biotypes $1 \mathrm{~B}$ and $2-5$ are considered to be pathogenic, while biotype 1A strains without classical virulence markers are regarded as non-pathogenic $[7,8,9]$. Nonetheless, according to McNally et al. [10], biotype $1 \mathrm{~A}$ strains are becoming the predominant pathogenic agent of yersiniosis (58\% of the reported cases) in the Commonwealth countries, surpassing bioserotype 4/O:3 strains. This observation was confirmed by a recent case-control study of diarrheic patients in Finland, where the majority of isolated Y. enterocolitica strains belonged to biotype 1A [11].

Address for correspondence: Agata Bancerz-Kisiel, Department of Epizootiology, Faculty of Veterinary Medicine, University of Warmia and Mazury in Olsztyn. E-mail: a.bancerz-kisiel@uwm.edu.pl

Received: 12 August 2015; accepted: 2 November 2015; first published on January 2017
It suggests that the previously determined pathogenicity criteria, based solely on bioserotype classification, may be insufficient.

The identification of virulence markers seems to be one of the reliable methods for pathogenicity determination. The $y$ st gene, which encodes the production of enterotoxin Yst (Yersinia stable toxin), is one of the most important and genetically stable virulence markers of Y. enterocolitica strains. Yst is synthesized as a polypeptide chain composed of a 30-amino acid C-terminal domain and an 18-amino acid $\mathrm{N}$-terminal signal sequence [12]. Yst has been divided into YstI enterotoxins (A, B and C) and the recently discovered YstII enterotoxin [9]. Classically, pathogenic strains possess the $y s t A$ gene that encodes YstA production [13].

Although Y. enterocolitica biotype 1A strains rarely produce YstA enterotoxin [14], more than $80 \%$ of them contain the $y s t B$ gene, which encodes the production of enterotoxin YstB - probably the main cause of diarrhea in clinical cases of yersiniosis caused by this biotype [13]. Rammamurthy et al. [15] demonstrated that $88.9 \%$ of Y. enterocolitica biotype 1A strains isolated from clinical cases of yersiniosis contributed to the accumulation of fluids in the intestines, which confirms their toxigenic potential. Therefore, $y s t B$ seems to be most appropriate virulence marker for determination of potential pathogenicity Y. enterocolitica biotype 1A strains. 
High-resolution melting (HRM) analysis is an emerging method for the detection of single nucleotide polymorphisms (SNPs) and for SNPs-based genotyping [16, 17]. In this method, the reduction in fluorescence is carefully monitored when a PCR product stained with a double-strand-specific fluorescent dye is heated through its melting temperature $\left(T_{m}\right)[18]$. HRM analysis is a single step procedure in a closed tube, and unlike in traditional melting analyses, its results are recorded in the shape of a melting curve [18].

The objective of the article was a study of single nucleotide polymorphism in the $y s t B$ gene of $Y$. enterocolitica strains isolated from various wild animal species.

\section{MATERIALS AND METHOD}

The study utilized $88 Y$. enterocolitica biotype 1A isolates obtained from different wild animal species (Tab. 1). 41 $Y$. enterocolitica isolates were collected from harvested wild boar, roe deer, red deer and wild ducks immediately after the hunt. Forty-seven Y. enterocolitica isolates were obtained from three different regions of cold-stored carcasses of wild animals. Primary identification involved bacteriological methods, biotyping, serotyping and detection of virulence markers as described in previous papers $[2,3,19]$. Detailed characteristics of the isolated $Y$. enterocolitica strains are presented in Table 1.

Genomic DNA was isolated with the use of the Genomic Mini kit (A\&A Biotechnology, Gdynia, Poland) according to the manufacturer's instructions, and it was stored at $-20^{\circ} \mathrm{C}$ for further analyses.

All HRM analyses were performed in the Rotor-Gene $6000^{\mathrm{TM}}$ real-time analyzer (Corbett Life Science, Sydney, Australia) using the PCR HRM curve analysis assay and Eva Green saturating dye (Type-it HRM PCR Kit, Qiagen, Hilden, Germany). Primer sequences used in the reaction: $y s t B-1$ (Forward) 5'TGTCAGCATTTATTCTCAACT3' and ystB-2 (Reverse) 5'GCCGATAATGTATCATCAAG3' were previously described by Bancerz-Kisiel et al. [1]. $25 \mu$ reaction mixtures were composed of $12.5 \mu \mathrm{l}$ of $2 \mathrm{x}$ HRM PCR Master Mix, $10.15 \mu \mathrm{l}$ of RNase-free water, $1.75 \mu \mathrm{l}$ of the primer mix (final concentration of $0.7 \mu \mathrm{M}$ each) and $0.6 \mu \mathrm{l}$ of DNA (50 ng/reaction). The cycling conditions were: $95^{\circ} \mathrm{C}$ for $5 \mathrm{~min}$; 40 cycles of $95^{\circ} \mathrm{C}$ for $10 \mathrm{~s}, 46^{\circ} \mathrm{C}$ for $30 \mathrm{~s}$, and $72^{\circ} \mathrm{C}$ for $10 \mathrm{~s}$. The amplified DNA was subjected to $\mathrm{HRM}$ at $0.1^{\circ} \mathrm{C}$ increments at temperatures ranging from $65^{\circ} \mathrm{C}-90^{\circ} \mathrm{C}$.

Genotypes were identified based on the shape of the HRM curve observed in the Rotor-Gene software after normalization of HRM curves. RotorGene 6000 Series Software 1.7. was used for melting curve analysis. Samples of each of the four SNP genotypes and 10 variations were subjected to direct sequencing to verify genotyping results (Genomed Sp. z o.o., Warsaw, Poland). Sequence data from the examined strains were compared with the nucleotide sequence of Y. enterocolitica DNA for Yersinia Heat-stable Enterotoxin Type B complete cds, registered in GenBank under accession no. D88145.1, in the BLASTN vs. 2.2.18 program [20]. Multiple sequence alignment was performed in ClustalW [21] incorporated into the freeware Computational Evolutionary Biology package MEGA version 5.2.1. [22]. Nucleotide sequences were presented graphically in BioEdit v.7.2.0. software.

\section{RESULTS}

Defining a $y s t B$ gene fragment suitable for HRM was a compromise between minimizing the size of the fragment in order to simplify reaction and maximizing the size of the fragment so as to maximize the number of detected mutations. Initial experiments involved $y s t B$ gene fragments with a length of more than $179 \mathrm{bp}$ (base pairs), which were used in the final stage of this study. The fragments were amplified by primers designed based on the $y s t B$ gene sequence (GenBank Accession No. D88145.1) in the PrimerBLAST programme available on the National Centre for Biotechnology Information (NCBI) website. These attempts, however, were unsuccessful, and the newly-designed primer pairs were unsuitable for $y s t B$ HRM analysis. Primers that were applied in previous studies by the authors of the presented study to detect $y s t B$, proved to be effective.

HRM curves were compared based on shape and $T_{m}$ values, they were normalized and difference graphs were plotted (Fig. 1). Examination of the normalized curves using normalization regions of 73-75 and 81-83 revealed the presence of 4 regular genotypes (G1, G2, G3, G4). 10 HRM curves with confidence percentage lower than 90 were defined as variations (one of them is presented on Fig. 1). 24 of the examined $Y$. enterocolitica strains were classified as G1, 18 strains as a G2, 21 strains as a G3, and 15 strains as a G4. The $y s t B$ nucleotide sequences from each of the 4 genotypes and nucleotide sequences of 10 variations were directly sequenced to verify HRM analysis. Direct sequencing revealed that the examined nucleotide sequences (after cutting and processing) had a length of $153 \mathrm{bp}$ according to the NCBI. They were linked in position 41-194 in Y. enterocolitica DNA for Yersinia Heat-stable Enterotoxin Type B complete cds (GenBank Accession No. D88145.1).

A sequence alignment analysis of nucleotide sequences classified as G1 revealed $100 \%$ similarity with the Y. enterocolitica D88145.1 sequence (Fig. 2). Analysis of sequences of $\mathrm{G} 2$ revealed one point mutation in the examined region: transition T111A (Fig. 2). One mutation was also found in $y s t B$ nucleotide sequences of G3, but SNP was placed in a different gene region - transition G193A (Fig. 2). By contrast, 2 SNPs - transitions G92C and T111A - were identified in $y s t B$ nucleotide sequences of G4 (Fig. 2). Direct sequencing of 10 variations revealed that none of them were correlated with regular genotypes. 5 new variants of $y s t B$ nucleotide sequence were observed. 3 variations (V1) were characterized by one point mutation - transition G129A (Fig. 2). 2 SNPs were detected in the subsequent 5 variations, but they were located at different positions for a given group of strains: V2 - transitions: T111A and G193A; V3 - transitions: C118T and G193A; V4 - transitions: C141A and G193A (Fig. 2). In two variations (V5), 19 SNPs were found in the examined nucleotide sequences: G83A, T93A, A109G, G114T, C116T, A123G, T134C, T142G, T144C, A150C, G162A, T165G, T170G, T174A, T177G, G178A, A179G, A184G and G193A (Fig. 2). Variations were found only in Y. enterocolitica isolates from cold-stored carcasses of wild animals.

$Y$. enterocolitica strains from wild ducks were isolated only from samples collected immediately after harvest. 60\% of these strains belonged to G1, and $40 \%$ - to G4 (Tab. 2). $Y$. enterocolitica strains isolated from roe deer immediately after harvest belonged to G2, whereas in the group of strains isolated from cold-stored carcasses, genotypic diversity was 
Table 1. Genotypes of $Y$. enterocolitica biotype 1 A strains analyzed in the study

\begin{tabular}{|c|c|c|c|c|c|c|c|c|}
\hline \multirow[t]{2}{*}{ Strain } & \multirow[t]{2}{*}{ Host } & \multirow{2}{*}{$\begin{array}{l}\text { Sampling } \\
\text { site }\end{array}$} & \multirow{2}{*}{$\begin{array}{l}\text { Year of } \\
\text { isola- } \\
\text { tion }\end{array}$} & \multirow{2}{*}{$\begin{array}{l}\text { Sero- } \\
\text { type }\end{array}$} & \multicolumn{3}{|c|}{ Virulence markers } & \multirow{2}{*}{$\begin{array}{l}\text { Geno- } \\
\text { type }\end{array}$} \\
\hline & & & & & ail & ystA & ystB & \\
\hline Ka16PSB & wild duck & Cloaca & 2010 & O:8 & & & + & 4 \\
\hline Ka27PSB & wild duck & Cloaca & 2010 & O:8 & & & + & 4 \\
\hline Ka32PSB & wild duck & Cloaca & 2010 & $0: 5$ & & & + & 1 \\
\hline Ka35PSB & wild duck & Cloaca & 2010 & O:8 & & & + & 1 \\
\hline Ka38PSB & wild duck & Cloaca & 2010 & $\mathrm{Nl}^{*}$ & & & + & 1 \\
\hline K6ITC & roe deer & Rectum & 2010 & $\mathrm{NI}$ & & & + & 2 \\
\hline K6PSB & roe deer & Rectum & 2010 & $\mathrm{NI}$ & & & + & 2 \\
\hline J2ITC & red deer & Rectum & 2010 & O:5 & & & + & 1 \\
\hline J12PSB & red deer & Rectum & 2010 & $\mathrm{NI}$ & & & + & 1 \\
\hline 1PSB & wild boar & Rectum & 2011 & $\mathrm{NI}$ & + & & + & 4 \\
\hline $5 P S B$ & wild boar & Rectum & 2011 & $\mathrm{NI}$ & & & + & 3 \\
\hline 9PSB & wild boar & Rectum & 2011 & $\mathrm{NI}$ & & & + & 3 \\
\hline 16PSB & wild boar & Rectum & 2011 & O:8 & & & + & 3 \\
\hline 17ITC & wild boar & Rectum & 2011 & $0: 27$ & & & + & 3 \\
\hline 64ITC & wild boar & Rectum & 2012 & $\mathrm{NI}$ & + & & + & 3 \\
\hline 64PSB & wild boar & Rectum & 2012 & $\mathrm{NI}$ & + & & + & 3 \\
\hline 68PSB & wild boar & rectum & 2012 & $\mathrm{NI}$ & & & + & 3 \\
\hline 69ITC & wild boar & rectum & 2012 & $\mathrm{NI}$ & & & + & 1 \\
\hline 69PSB & wild boar & rectum & 2012 & $\mathrm{NI}$ & & & + & 3 \\
\hline 76PSB & wild boar & rectum & 2012 & $\mathrm{NI}$ & & & + & 4 \\
\hline 77PSB & wild boar & rectum & 2012 & O:8 & & & + & 3 \\
\hline 101PSB & wild boar & rectum & 2012 & $\mathrm{NI}$ & + & & + & 2 \\
\hline 104ITC & wild boar & rectum & 2012 & $\mathrm{NI}$ & + & & + & 4 \\
\hline 104PSB & wild boar & rectum & 2012 & $\mathrm{NI}$ & + & & + & 2 \\
\hline 136PSB & wild boar & rectum & 2012 & $\mathrm{NI}$ & & & + & 2 \\
\hline 143ITC & wild boar & rectum & 2012 & $0: 27$ & + & & + & 2 \\
\hline 143PSB & wild boar & rectum & 2012 & $\mathrm{NI}$ & + & & + & 2 \\
\hline 148PSB & wild boar & rectum & 2012 & $\mathrm{NI}$ & + & & + & 2 \\
\hline 149PSB & wild boar & rectum & 2012 & $\mathrm{NI}$ & + & & + & 2 \\
\hline 150ITC & wild boar & rectum & 2012 & $\mathrm{NI}$ & & & + & 4 \\
\hline 150PSB & wild boar & rectum & 2012 & $\mathrm{NI}$ & & & + & 4 \\
\hline 152PSB & wild boar & rectum & 2012 & $\mathrm{NI}$ & & & + & 4 \\
\hline 156ITC & wild boar & rectum & 2012 & $\mathrm{NI}$ & & & + & 3 \\
\hline 159PSB & wild boar & rectum & 2012 & $\mathrm{NI}$ & & & + & 3 \\
\hline 177PSB & wild boar & rectum & 2012 & $\mathrm{NI}$ & & & + & 4 \\
\hline 179PSB & wild boar & rectum & 2012 & $\mathrm{NI}$ & & & + & 2 \\
\hline 206PSB & wild boar & rectum & 2013 & $\mathrm{NI}$ & & & + & 3 \\
\hline 224PSB & wild boar & rectum & 2013 & $\mathrm{NI}$ & & & + & 3 \\
\hline 248ITC & wild boar & rectum & 2013 & $\mathrm{NI}$ & & & + & 1 \\
\hline 256PSB & wild boar & rectum & 2013 & $\mathrm{NI}$ & + & & + & 1 \\
\hline 258PSB & wild boar & rectum & 2013 & $\mathrm{NI}$ & & & + & 1 \\
\hline $1(\mathrm{~T}) \mathrm{PSB}$ & roe deer & $\begin{array}{c}\text { carcass; } \\
\text { peritoneum }\end{array}$ & 2013 & O:8 & & & + & V1 \\
\hline $1(\mathrm{O}) \mathrm{PSB}$ & roe deer & $\begin{array}{c}\text { carcass; } \\
\text { perineum }\end{array}$ & 2013 & $\mathrm{NI}$ & & & + & V1 \\
\hline 2(M)PSB & roe deer & $\begin{array}{l}\text { carcass; } \\
\text { tonsil area }\end{array}$ & 2013 & $\mathrm{NI}$ & & & + & 2 \\
\hline 2(T)PSB & roe deer & $\begin{array}{c}\text { carcass; } \\
\text { peritoneum }\end{array}$ & 2013 & $\mathrm{NI}$ & & & + & 1 \\
\hline 2(O)PSB & roe deer & $\begin{array}{c}\text { carcass; } \\
\text { perineum }\end{array}$ & 2013 & $\mathrm{NI}$ & & & + & V1 \\
\hline
\end{tabular}

\begin{tabular}{|c|c|c|c|c|c|c|c|}
\hline \multirow[t]{2}{*}{ Strain } & \multirow[t]{2}{*}{ Host } & \multirow{2}{*}{$\begin{array}{l}\text { Sampling } \\
\text { site }\end{array}$} & \multirow{2}{*}{$\begin{array}{l}\text { Year of } \\
\text { isola- } \\
\text { tion }\end{array}$} & \multirow{2}{*}{$\begin{array}{l}\text { Sero- } \\
\text { type }\end{array}$} & \multicolumn{2}{|c|}{ Virulence markers } & \multirow{2}{*}{$\begin{array}{l}\text { Geno- } \\
\text { type }\end{array}$} \\
\hline & & & & & ail ystA & ystB & \\
\hline 6(T)PSB & roe deer & $\begin{array}{c}\text { carcass; } \\
\text { peritoneum }\end{array}$ & 2013 & $\mathrm{NI}$ & & + & 1 \\
\hline 8(T)PSB & roe deer & $\begin{array}{c}\text { carcass; } \\
\text { peritoneum }\end{array}$ & 2013 & O:27 & & + & 2 \\
\hline 8(O)PSB & roe deer & $\begin{array}{c}\text { carcass; } \\
\text { perineum }\end{array}$ & 2013 & $\mathrm{NI}$ & & + & 3 \\
\hline 9(M)PSB & roe deer & $\begin{array}{c}\text { carcass; } \\
\text { tonsil area }\end{array}$ & 2013 & $\mathrm{NI}$ & & + & V5 \\
\hline 10(O)PSB & roe deer & $\begin{array}{c}\text { carcass; } \\
\text { perineum }\end{array}$ & 2013 & $\mathrm{NI}$ & & + & 2 \\
\hline 11(M)PSB & roe deer & $\begin{array}{c}\text { carcass; } \\
\text { tonsil area }\end{array}$ & 2013 & $\mathrm{NI}$ & & + & 4 \\
\hline 11(O)PSB & roe deer & $\begin{array}{c}\text { carcass; } \\
\text { perineum }\end{array}$ & 2013 & $\mathrm{NI}$ & & + & 1 \\
\hline 12(M)PSB & roe deer & $\begin{array}{l}\text { carcass; } \\
\text { tonsil area }\end{array}$ & 2013 & $\mathrm{NI}$ & & + & 2 \\
\hline 12(T)PSB & roe deer & $\begin{array}{c}\text { carcass; } \\
\text { peritoneum }\end{array}$ & 2013 & O:8 & & + & 2 \\
\hline 13(T)PSB & roe deer & $\begin{array}{c}\text { carcass; } \\
\text { peritoneum }\end{array}$ & 2013 & $\mathrm{NI}$ & & + & V2 \\
\hline 17(M)PSB & roe deer & $\begin{array}{l}\text { carcass; } \\
\text { tonsil area }\end{array}$ & 2013 & $\mathrm{NI}$ & & + & 4 \\
\hline 18(M)PSB & roe deer & $\begin{array}{c}\text { carcass; } \\
\text { tonsil area }\end{array}$ & 2013 & $\mathrm{NI}$ & & + & 2 \\
\hline 20(M)PSB & roe deer & $\begin{array}{c}\text { carcass; } \\
\text { tonsil area }\end{array}$ & 2013 & $\mathrm{NI}$ & & + & V2 \\
\hline 24(M)PSB & roe deer & $\begin{array}{c}\text { carcass; } \\
\text { tonsil area }\end{array}$ & 2013 & $\mathrm{NI}$ & & + & V5 \\
\hline 32(M)PSB & red deer & $\begin{array}{c}\text { carcass; } \\
\text { tonsil area }\end{array}$ & 2013 & $\mathrm{NI}$ & & + & 2 \\
\hline 33(T)PSB & red deer & $\begin{array}{c}\text { carcass; } \\
\text { peritoneum }\end{array}$ & 2013 & O:8 & & + & 4 \\
\hline 34(M)PSB & red deer & $\begin{array}{l}\text { carcass; } \\
\text { tonsil area }\end{array}$ & 2013 & $\mathrm{NI}$ & & + & V3 \\
\hline 34(T)PSB & red deer & $\begin{array}{c}\text { carcass; } \\
\text { peritoneum }\end{array}$ & 2013 & $0: 3$ & & + & 4 \\
\hline 34(O)PSB & red deer & $\begin{array}{c}\text { carcass; } \\
\text { perineum }\end{array}$ & 2013 & $\mathrm{NI}$ & & + & V4 \\
\hline 35(M)PSB & red deer & $\begin{array}{c}\text { carcass; } \\
\text { tonsil area }\end{array}$ & 2013 & O:5 & & + & 1 \\
\hline $35(0) P S B$ & red deer & $\begin{array}{c}\text { carcass; } \\
\text { perineum }\end{array}$ & 2013 & $0: 3$ & & + & 1 \\
\hline 36(T)PSB & red deer & $\begin{array}{c}\text { carcass; } \\
\text { peritoneum }\end{array}$ & 2013 & $\mathrm{NI}$ & & + & 4 \\
\hline 36(O)PSB & red deer & $\begin{array}{l}\text { carcass; } \\
\text { perineum }\end{array}$ & 2013 & $\mathrm{NI}$ & & + & 3 \\
\hline 43(O)PSB & wild boar & $\begin{array}{c}\text { carcass; } \\
\text { perineum }\end{array}$ & 2013 & $\mathrm{NI}$ & & + & V4 \\
\hline 46(M)PSB & wild boar & $\begin{array}{c}\text { carcass; } \\
\text { tonsil area }\end{array}$ & 2013 & O:8 & & + & 3 \\
\hline 46(T)PSB & wild boar & $\begin{array}{c}\text { carcass; } \\
\text { peritoneum }\end{array}$ & 2013 & O:8 & & + & 1 \\
\hline 46(O)PSB & wild boar & $\begin{array}{l}\text { carcass; } \\
\text { perineum }\end{array}$ & 2013 & $\mathrm{NI}$ & & + & 3 \\
\hline 47(T)PSB & wild boar & $\begin{array}{c}\text { carcass; } \\
\text { peritoneum }\end{array}$ & 2013 & O:5 & & + & 1 \\
\hline 47(O)PSB & wild boar & $\begin{array}{l}\text { carcass; } \\
\text { perineum }\end{array}$ & 2013 & O:5 & & + & 4 \\
\hline 48(M)PSB & wild boar & $\begin{array}{c}\text { carcass; } \\
\text { tonsil area }\end{array}$ & 2013 & $\mathrm{NI}$ & & + & 2 \\
\hline 48(O)PSB & wild boar & $\begin{array}{c}\text { carcass; } \\
\text { perineum }\end{array}$ & 2013 & $\mathrm{NI}$ & & + & 1 \\
\hline 49(M)PSB & wild boar & $\begin{array}{c}\text { carcass; } \\
\text { tonsil area }\end{array}$ & 2013 & O:8 & & + & 1 \\
\hline 49(O)PSB & wild boar & $\begin{array}{l}\text { carcass; } \\
\text { perineum }\end{array}$ & 2013 & $\mathrm{NI}$ & & + & 1 \\
\hline 50(T)PSB & wild boar & $\begin{array}{c}\text { carcass; } \\
\text { peritoneum }\end{array}$ & 2013 & O:5 & & + & 1 \\
\hline 50(O)PSB & wild boar & $\begin{array}{c}\text { carcass; } \\
\text { perineum }\end{array}$ & 2013 & O:8 & & + & 1 \\
\hline $51(\mathrm{~T}) \mathrm{ITC}$ & wild boar & $\begin{array}{c}\text { carcass; } \\
\text { peritoneum }\end{array}$ & 2013 & O:5 & & + & 3 \\
\hline 51(M)PSB & wild boar & $\begin{array}{c}\text { carcass; } \\
\text { tonsil area }\end{array}$ & 2013 & O:5 & & + & 1 \\
\hline 51(T)PSB & wild boar & $\begin{array}{c}\text { carcass; } \\
\text { peritoneum }\end{array}$ & 2013 & O:5 & & + & 3 \\
\hline $51(0) P S B$ & wild boar & $\begin{array}{l}\text { carcass; } \\
\text { perineum }\end{array}$ & 2013 & $\mathrm{NI}$ & & + & 3 \\
\hline 58(O)PSB & wild boar & $\begin{array}{c}\text { carcass; } \\
\text { perineum }\end{array}$ & 2013 & $\mathrm{NI}$ & & + & 1 \\
\hline 59(M)PSB & wild boar & $\begin{array}{l}\text { carcass; } \\
\text { tonsil area }\end{array}$ & 2013 & $\mathrm{NI}$ & & + & 3 \\
\hline 60(T)PSB & wild boar & $\begin{array}{c}\text { carcass; } \\
\text { peritoneum }\end{array}$ & 2013 & O:8 & & + & 1 \\
\hline
\end{tabular}



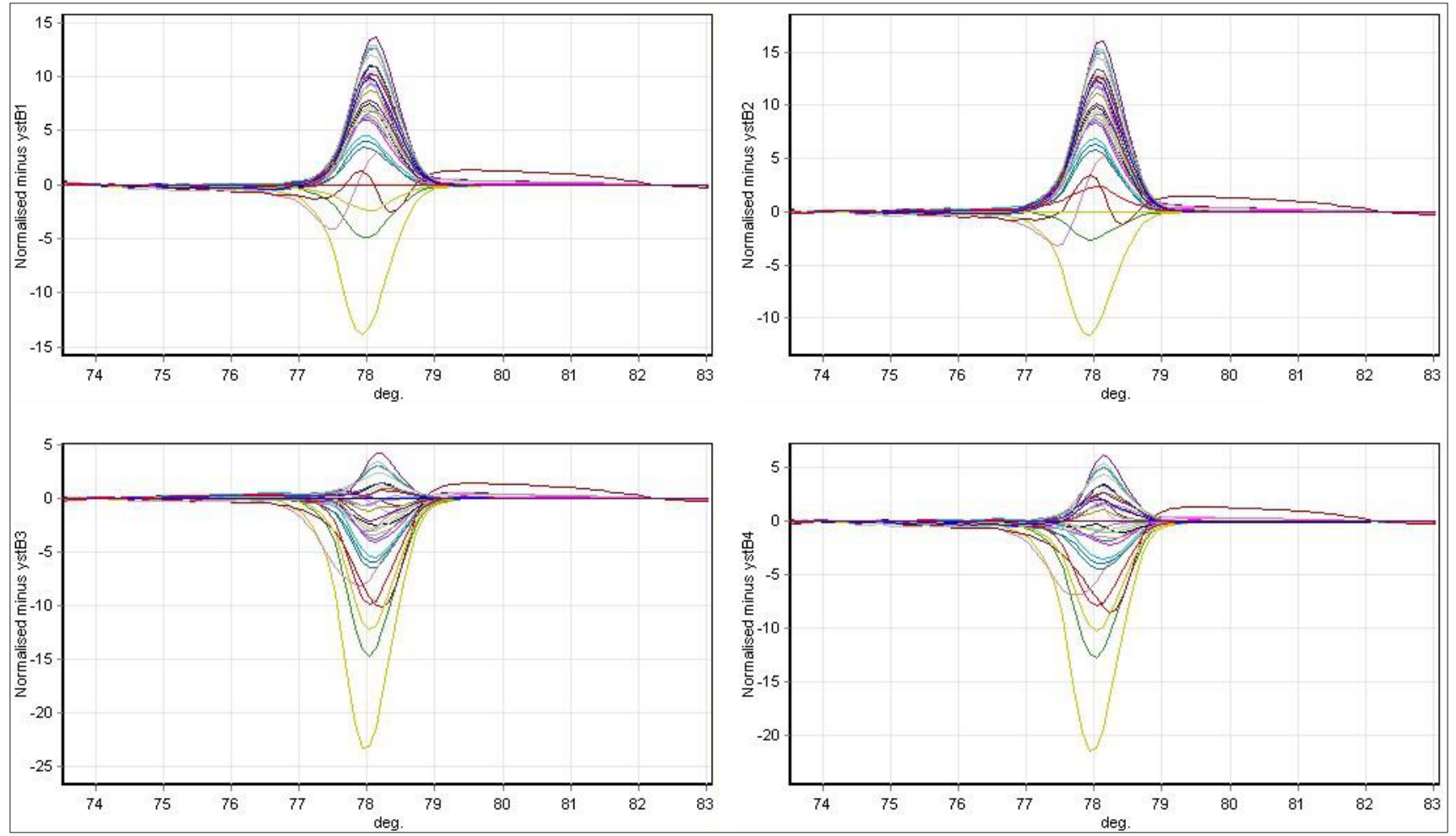

Figure 1. HRM difference graphs of $Y$. enterocolitica ystB gene.

Figure shows 4 genotypes (G1, G2, G3 and G4) and some variations of the examined nucleotide sequence ystB gene $Y$. enterocolitica strains isolated from wild animals detected using HRM

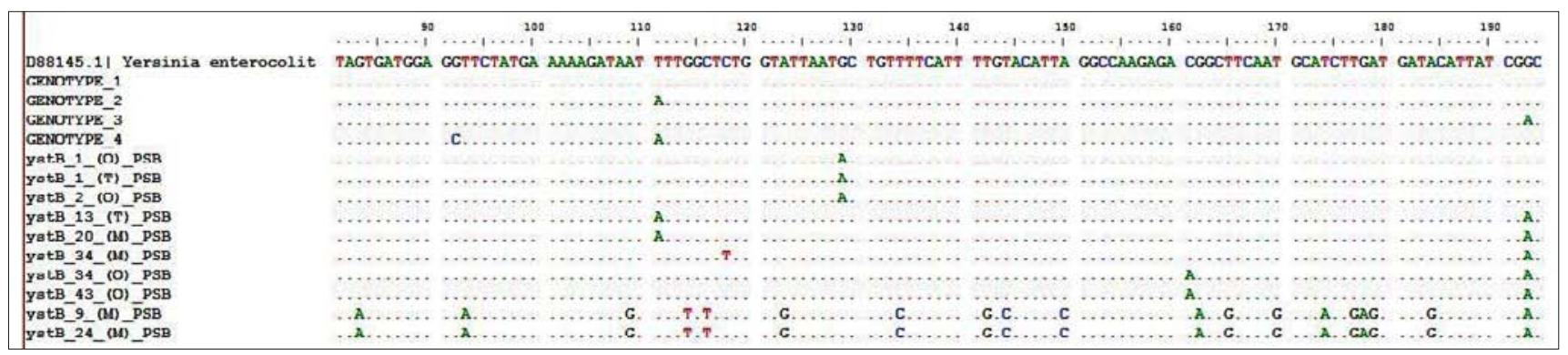

Figure 2. Single nucleotide polymorphism of $Y$. enterocolitica yst $B$ gene.

Phylogenetic analysis of G1 nucleotide sequences ystB gene $Y$. enterocolitica strains isolated from wild animals revealed $100 \%$ similarity with the $Y$. enterocolitica D88145.1 sequence. Analysis of $\mathrm{G} 2$ nucleotide sequences ystB gene revealed one point mutation in the examined region: transition T111A. One mutation was also found in nucleotide sequences of G3- transition G193A. Two SNPs - transitions G92C and T111A - were identified in ystB nucleotide sequences of G4. Three variations were characterized by one point mutation - transition G129A. Two SNPs were detected in subsequent five variations, but they were located at different positions for a given group of strains - transitions: T111A and G193A; C118T and G193A; C141A and G193A. In two variations, 19 SNPs were found in the examined nucleotide sequences: G83A, T93A, A109G, G114T, C116T, A123G, T134C, T142G, T144C, A150C, G162A, T165G, T170G, T174A, T177G, G178A, A179G, A184G and G193A.

higher. More than $30 \%$ of those strains also represented G2, but a significant number of variations and some G1 and G4 were also noted (Tab. 2). Y. enterocolitica strains isolated from red deer immediately after harvest were classified to G4. Similar to roe deer, genotypic diversity was observed in red deer only in the group of strains isolated from cold-stored carcasses. More than 30\% of those strains also represented G4, but a significant number of variations and some G1 were observed (Tab. 2). In the group of strains isolated from wild boar immediately after harvest, more than $40 \%$ belonged to G3, but a high number of G2 and G4 was noted (Tab. 2). By contrast, in the group of strains isolated from cold-stored wild boar carcasses, the predominant was G1 (52.6\%), G3 was detected in $31.5 \%$ of examined strains (Tab. 2).

It should also be noted that different genotypes were identified in 11 individuals from which more than one Y. enterocolitica strain was isolated. In some cases, up to
3 genotypes were determined in samples collected from one animal; for example, 2(M)PSB, 2(T)PSB and 2(O)PSB. Detailed characteristics of those strains are shown in Table 1. Interestingly, the presence of ail gene in some of the examined $Y$. enterocolitica strains (ail is rarely detected in biotype 1A, $y s t B$ positive strains) did not affect on genotype. In this group of ail positive strains, all genotypes were detected.

\section{DISCUSSION}

In the presented study, $88 Y$. enterocolitica strains were examined with the use of $y s t B$ SNPs detection by HRM analysis. According to best knowledge of the authos', this is one of the few studies where the HRM method was deployed to characterize Y. enterocolitica strains. Bancerz-Kisiel et al. [16] used HRM to detect possible mutations in the ymoA (Yersinia 
Table 2. Comparison of genotypes of $Y$. enterocolitica strains isolated from different wild animal species, immediately after the hunt and from coldstored carcasses

\begin{tabular}{|c|c|c|c|c|c|c|c|c|c|c|c|c|}
\hline \multirow{3}{*}{ Source } & & \multirow{3}{*}{ Strain No. } & \multicolumn{10}{|c|}{ Genotype } \\
\hline & & & \multicolumn{2}{|c|}{1} & \multicolumn{2}{|c|}{2} & \multicolumn{2}{|c|}{3} & \multicolumn{2}{|c|}{4} & \multicolumn{2}{|c|}{ Variation } \\
\hline & & & No. & $\%$ & No. & $\%$ & No. & $\%$ & No. & $\%$ & No. & $\%$ \\
\hline Wild duck & after shooting & 5 & 3 & 60.0 & - & - & - & - & 2 & 40.0 & - & - \\
\hline \multirow{2}{*}{ Roe deer } & after shooting & 2 & - & - & 2 & 100.0 & - & - & - & - & - & - \\
\hline & cold-stored & 18 & 3 & 16.7 & 6 & 33.3 & 1 & 5.6 & 2 & 11.1 & 6 & 33.3 \\
\hline Red deer & cold-stored & 10 & 2 & 20.0 & 1 & 10.0 & 1 & 10.0 & 3 & 30.0 & 3 & 30.0 \\
\hline \multirow{2}{*}{ Wild boar } & after shooting & 32 & 4 & 12.5 & 8 & 25.0 & 13 & 40.6 & 7 & 21.9 & - & - \\
\hline & cold-stored & 19 & 10 & 52.6 & 1 & 5.3 & 6 & 31.5 & 1 & 5.3 & 1 & 5.3 \\
\hline
\end{tabular}

modulator) gene region, and to evaluate their influence on the enterotoxic properties of Y. enterocolitica strains. By contrast, Souza and Falcao [23] used HRM analysis as the method for Y. enterocolitica genotyping. They were searching for SNPs detection in 50 Y. enterocolitica strains of biotypes $1 \mathrm{~A}, 1 \mathrm{~B}, 2$, 3, 4, and 5. Different melting profiles were determined for 7 fragments of 50 genotyped Y. enterocolitica strains, and the SNPs identified in the $h s p 60$-SNP1 fragment were identified only after heteroduplex formation. Souza and Falcao [23] developed a phylogenetic analysis based on HRM which confirmed the grouping of $Y$. enterocolitica biotypes into 3 clusters in view of their pathogenic potential.

The current study is the first to describe the application of the HRM method for genotypic the characteristics of $Y$. enterocolitica biotype 1A strains. The origin of $Y$. enterocolitica strains, isolated from various species of wild animals, should also be noted. SNPs detection in one of the most important for this biotype virulence markers - ystB, revealed 14 different melting profiles. Four of them were detected more frequently and were defined as regular genotypes, whereas 10 were defined as variations. Direct sequencing of variations revealed 5 new variants of the $y s t B$ nucleotide sequence, which differed from regular genotypes. Variations were detected only in Y. enterocolitica strains isolated from cold-stored carcasses. The above could indicate that $Y$. enterocolitica multiplies under optimal growth conditions, and new variants are probably created as a result of direct contact between microorganisms.

Our findings could also point to the predominance of some genotypes in Y. enterocolitica isolated from particular wild animals species. In isolates from wild ducks Y. enterocolitica was represented mainly by G1. Y. enterocolitica strains isolated from red deer belonged in majority to G2, while isolates from roe deer to G1 and G4. The predominant genotype in isolates from wild boars was G3. This is the first study described $Y$. enterocolitica strains isolated from wild animal in such detail, therefore, our results cannot be compared with other authors' findings. Further studies involving a higher number of samples is required to substantiate our observations.

The HRM-based method for genotyping Y. enterocolitica $y s t B$ positive strains revealed that a single animal can be a source of more than one genotype of Y. enterocolitica. Interestingly, the above observation was not always correlated with differences in the serotype of the examined isolates. Similar observations were made by Souza and Falcao [23], who demonstrated that strains with different serotypes produced identical HRM profiles. According to the cited authors, despite considerable heterogeneity in $Y$. enterocolitica $\mathrm{O}$ antigens that determine serotype, strains are related genetically.

Authors of this study did not have an access to any $y s t B$ positive $Y$. enterocolitica biotype 1A strain, which would be isolated from clinical case of yersiniosis. These infections manifested by diarrhea are very rare, difficult to proper diagnose and then $Y$. enterocolitica biotype 1A isolation. However, comparing clinical isolates with other biotype 1A strains using HRM method developed in this study would be interesting in the context of widely discussed problem of diversified pathogenicity $Y$. enterocolitica $y s t B$ positive strains.

\section{CONCLUSIONS}

To conclude, the results of the HRM and sequences analysis indicate that Y. enterocolitica biotype 1A strains are highly diverse. SNP-based genotypes are correlated with the host species, but further work is needed to validate this observation. The proposed HRM method could be used in epidemiological investigation to expand existing knowledge of genetic variability of $Y$. enterocolitica ystB positive strains. In the view of the zoonotic properties of Y. enterocolitica this method could be also applied to analyze Y. enterocolitica strains isolated from human cases of yersiniosis. Undisputed advantage of this method would be their adoption to predicting pathogenic potential of examined $Y$. enterocolitica biotype $1 \mathrm{~A}$ strains.

\section{Acknowledgments}

This study was supported by the National Science Centre (NCN, grant No. N N308 609338).

\section{REFERENCES}

1. Bancerz-Kisiel A, Szczerba-Turek A, Platt-Samoraj A, Socha P, Szweda W. Application of multiplex PCR for the evaluation of the occurrence of ail, $y s t A$ and $y s t B$ genes in Yersinia enterocolitica strains isolated from wild boars (Sus scrofa). Bull Vet Inst Pulawy 2009; 53: 351-355.

2. Bancerz-Kisiel A, Szczerba-Turek A, Lipczyńska K, Stenzel T, Szweda W. Bioserotypes and virulence markers of Yersinia enterocolitica strains isolated from mallards (Anas platyrhynchos) and pheasants (Phasianus colchicus). J Food Prot. 2012; 75: 2219-2222.

3. Bancerz-Kisiel A, Szczerba-Turek A, Platt-Samoraj A, Socha P, Szweda W. Roe deer (Capreolus capreolus) and red deer (Cervus elaphus) as an environmental reservoir and potential source of Yersinia enterocolitica infection for humans. Pol J Vet Sci. 2014; 17: 315-319. 
4. Bhaduri S, Wesley I, Bush EJ. Prevalence of Pathogenic Yersinia enterocolitica Strains in Pigs in the United States. Appl Environ Microbiol. 2005; 71: 7117-7121.

5. Bucher M, Meyer C, Grötzbach B, Wacheck S, Stolle A, FredrikssonAhomaa M. Epidemiological data on pathogenic Yersinia enterocolitica in Southern Germany during 2000-2006. Foodborne Pathog Dis. 2008; 5: 273-280.

6. Fredriksson-Ahomaa M, Wacheck S, Bonke R, Stephan R. Different Enteropathogenic Yersinia Strains Found in Wild Boars and Domestic Pigs. Foodborne Pathog Dis. 2011; 8: 733-737.

7. Fredriksson-Ahomaa M, Stolle A, Stephan R. Prevalence of pathogenic Yersinia enterocolitica in pigs slaughtered at a Swiss abattoir. Int J Food Microbiol. 2007; 119: 207-212.

8. Singh I, Virdi JS. Production of Yersinia stable toxin (YST) and distribution of $y$ st genes in biotype 1A strains of Yersinia enterocolitica. J Med Microbiol. 2004; 53: 1065-1068.

9. Tennant SM, Skinner NA, Joe A, Robins-Browne RM. Homologues of Insecticidal Toxin Complex Genes in Yersinia enterocolitica Biotype $1 \mathrm{~A}$ and Their Contribution to Virulence. Infect Immun. 2005; 73: 6860-6867.

10. McNally A, Dalton T, La RagioneRM, Stapleton K, Manning G, Newell DG. Yersinia enterocolitica isolates of differing biotypes from humans and animals are adherent, invasive and persist in macrophages, but differ in cytokine secretion profiles in vitro. J Med Microbiol. 2006; 55: $1725-1734$

11. Huovinen E, Sihvonen LM, Virtanen MJ, Haukk, K, Siitonen A, Kuusi M. Symptoms and sources of Yersinia enterocolitica-infection: a casecontrol study. BMC Infect Dis. 2010; 10: 122.

12. Bottone EJ. Yersinia enterocolitica: the charisma continues. Clin Microbiol. 1997; 10: 257-276.

13. Grant T, Bennett-Wood V, Robins-Browne RM. Identification of virulence-associated characteristics in clinical isolates of Yersinia enterocolitica lacking classical virulence markers. Infect Immun. 1998; 66: $1113-1120$
14. Sabina Y, Rahman A, Ramesh ChR, Montet D. Yersinia enterocolitica: Mode of Transmission, Molecular Insights of Virulence, and Pathogenesis of Infection. J Pathog. 2011; http://dx.doi.org/10.4061/2011/429069.

15. Ramamurthy T, Yoshino KI, Huang X, Balakrish Nair G, Carniel E, Maruyama T. The novel heat-stable enterotoxin subtype gene $(y s t B)$ of Yersinia enterocolitica: nucleotide sequence and distribution of the $y s t$ genes. Microb Pathog. 1997; 23: 189-200.

16. Bancerz-Kisiel A, Lipczyńska K, Szczerba-Turek A, Gospodarek E, Platt-Samoraj A. Szweda W. The use of the HRM method for identifying possible mutations in the ymoA gene region and evaluating their influence on the enterotoxic properties of Y. enterocolitica strains. BMC Vet Res. 2014; 10: 207-211.

17. Souza RA, Falcão JP. A novel high-resolution melting analysis-based method for Yersinia pseudotuberculosis genotyping. J Microbiol Methods 2012; 91: 329-335.

18. Merchant-Patel S, Blackall PJ, Templeton J, Price EP, Tong SY, Huygens F, et al. Campylobacter jejuni and Campylobacter coli genotyping by high-resolution melting analysis of a flaA fragment. Appl Environ Microbiol. 2010; 76: 493-499.

19. Bancerz-Kisiel A, Platt-Samoraj A, Szczerba-Turek A, Syczyło K, Szweda W. The first pathogenic Yersinia enterocolitica bioserotype 4/O:3 strain isolated from a hunted wild boar (Sus scrofa) in Poland. Epidemiol Infect. 2015; 143: 2758-2765.

20. Altschul SF, Madden TL, Schäffer AA, Zhang J, Zhang Z, Miller W, et al. Gapped BLAST and PSI-BLAST: a new generation of protein database search programs. Nucleic Acids Res. 1997; 25: 3389-3402.

21. Larkin MA, Blackshields G, Brown NP, Chenna R, McGettigan PA McWilliam, et al. Clustal W and Clustal X version 2.0. Bioinformatics. 2007; 23: 2947-2948.

22. Tamura K, Peterson D, Peterson N, Stecher G, Nei M, Kumar S. MEGA5: Molecular Evolutionary Genetics Analysis using Maximum Likelihood, Evolutionary Distance, and Maximum Parsimony Methods. Mol Biol Evol. 2011; 28: 2731-2739.

23. Souza RA, Falcão JP. A novel high-resolution melting analysis-based method for Yersinia enterocolitica genotyping. J Microbiol Methods. 2014; 106: 129-134. 